\title{
Inflated Production Quota Gains Paid for by a Consumption Tax
}

\author{
Troy G. Schmitz ${ }^{1}$, Andrew Schmitz ${ }^{2}$, Dwayne Haynes ${ }^{2}$ \\ ${ }^{1}$ Morrison School of Agribusiness and Resource Management, Arizona State University, Mesa, USA \\ ${ }^{2}$ Food and Resource Economics, Institute of Food and Agricultural Sciences (IFAS), \\ University of Florida, Gainesville, USA \\ Email: tschmitz@asu.edu, aschmitz@ufl.edu
}

Received December 9, 2011; revised January 11, 2012; accepted January 18, 2012

\begin{abstract}
We consider a production quota buyout that is paid for by a consumption tax. If producers are paid the true value of the quota via a consumption tax, the net producer gain is zero for the combined introduction and removal of quota (even though the quota value is positive) since the net gain to producers when the quota was introduced is equal to the net loss to producers when the production quota is removed. Therefore, the quota value does not measure the producer net gain from both the introduction and removal of the production quota. The quota value merely represents the consumption tax amount. This is also true if producers are paid (which is often the case) an inflated quota value that is more than the true quota value.
\end{abstract}

Keywords: Economic Efficiency; Economic Gains; Production Quotas

\section{Introduction}

Production quotas have been in existence for quite some time. In the United States, for example, many production quota programs were put into place in the 1930s. Since then, several of these programs have been eliminated. Examples include the US peanut and tobacco programs, which ended in 2002 and 2004, respectively, through government compensation to producers. Schmitz and Schmitz ([1,2]) considered a case (i.e., US peanut program buyout) where compensation to producers was paid for by monies from the US Treasury. They demonstrated theoretically that a payment based on the true value of the quota gave rise to the result that the value of quota exactly equaled the net positive gain to producers when the quota was introduced plus the net positive gain when it is removed. However, this is not the case when compensation is paid for through a consumer tax (e.g., under the tobacco program buyout, a tobacco tax was the source for compensation). If producers are paid the true value of the quota via a consumption tax, the net producer gain is zero (even though the quota value is positive) since the net gain to producers when the quota was introduced is equal to the net loss to producers when the production quota is removed. The quota value merely reflects the consumption tax. We also show that if producers, as often is the case, are paid more than the true quota value, the above result also holds.

\section{Theoretical Model}

\subsection{Period I}

Consider Figure 1 where $S$ is the supply schedule for good $x$ and $D$ is demand. In the absence of a production quota, the competitive price is $p_{0}$ and the corresponding output is $q_{0}$. Suppose we introduce a quota on production that restricts output to $q_{1}$. The price increases from $p_{0}$ to $p_{1}$. Using the theoretical constructs of welfare economics (Just et al. [3]), under the quota, consumers pay a higher price for the product which translates into a net cost to consumers of $\left(p_{1} p_{0} j a\right)$. The net producer gain from the quota is $\left(p_{1} p_{0} j a\right)-(b c j)$ which is smaller than the true quota value $\left(p_{1} p_{x} c a\right)$. The net societal cost is $(a c j)$.

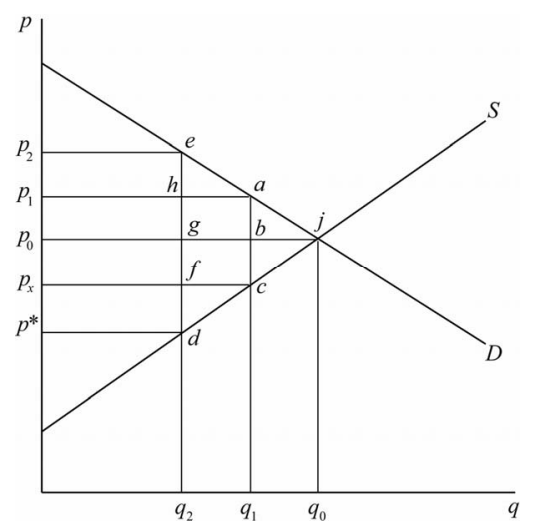

Figure 1. Production quota buyout: Inflated quota values. 


\subsection{Period II}

At the beginning of period II, the government announces that it will terminate the production quota program by compensating producers through a consumption tax (e.g., in the US tobacco quota buyout, unlike the US peanut production quota buyout case, the payout to producers for ending the tobacco program came about by means of a tobacco tax). Our results show that the effects of the buyout paid for by a consumption tax are very different from those where the monies to pay for the buyout come from the US Treasury (as in the case, for example, in the US buyout of the peanut program). For the latter, Schmitz and Schmitz ([2]) show that the true quota value is exactly equal to the net positive producer gain from the introduction of a quota plus the net positive producer gain from its removal. This is no longer true when compensation is made through a consumer tax.

Given a quota $q_{1}$, the true quota value totals $\left(p_{1} p_{x} c a\right)$. If the government terminates the program from revenue via a consumption tax of $\left(p_{1} p_{x} c a\right)$, the net producer gain from removal of the production quota is zero, but the true quota value is positive. This is because a production quota subsidy is a consumer tax that producers collect under a production quota scheme. In this case, the net gain to producers over the two periods is the gain to producers when the quota was introduced $\left\{\left(p_{1} p_{0} b a\right)-\right.$ $(b c j)\}$ plus the net loss when it is removed $\left\{\left(p_{1} p_{0} b a\right)-\right.$ $(b c j)\}$, which totals zero. Thus, if producers are only paid the true quota value, there is no incentive for them to lobby for termination of the production quota program.

Often in production quota buyout cases, producers are paid an amount in excess of the true quota value. In the buyout of the US tobacco program, for example, quota holders were paid two to three times more than the true quota value (Womach [4]). Consider the case where a payout is made for an inflated quota buyout $\left(p_{2} p^{*} d e\right)$ that exceeds the true quota value $\left(p_{1} p_{x} c a\right)$. For a quota buyout of $\left(p_{2} p^{*} d e\right)$, producers gain in Period II

$$
\left\{\left(p_{2} p_{1} h e\right)-(h d c a)\right\}+\left(p_{0} p^{*} d j\right)
$$

However, producers lose the consumption tax revenue of $\left(p_{2} p^{*} d e\right)$ when the program is terminated and competitive equilibrium is restored.

\subsection{Overall Effect of the Buyout}

We now show that the inflated quota value $\left(p_{2} p^{*} d e\right)$ is not equal to the net gain to producers from the introduction of the quota plus the net loss to producers when it is removed. The quota value is merely the amount of the consumption tax used to pay for the production quota buyout.

In period I, producers gain

$$
\left(p_{1} p_{0} g h\right)+(h g b a)-(b c j)
$$

In period II, producers gain

$$
\begin{aligned}
& \left(p_{2} p_{1} h e\right)-(h g b a)-(g f b c)-(f d c)+\left(p_{x} p^{*} d f\right) \\
& +(f d c)+\left(p_{0} p_{x} f g\right)+(g f c b)+(b c j)-\left(p_{2} p^{*} d e\right)
\end{aligned}
$$

After simplification, the net producer gain over both periods equals

$$
\begin{aligned}
& \left(p_{1} p_{0} g h\right)+\left(p_{2} p_{1} h e\right)+\left(p_{x} p^{*} d f\right)+\left(p_{0} p_{x} f g\right) \\
& -\left(p_{2} p^{*} d e\right)=0
\end{aligned}
$$

Therefore, the inflated quota value $\left(p_{2} p^{*} d e\right)$ does not equal the net producer gain over the two periods. The quota value is merely the amount of the consumption tax used to pay for the production quota buyout.

Why is this result different from Schmitz and Schmitz ([2]) where a buyout is paid for with money from the US Treasury? In their case, the quota value is equal to the net producer gains when the quota is introduced plus the net gains when it is removed. The difference can be seen below. In the Schmitz and Schmitz (2011) case, the net producer gain over the two periods is positive

$$
\left(p_{1} p_{0} g h\right)+\left(p_{2} p_{1} h e\right)+\left(p_{x} p^{*} d f\right)+\left(p_{0} p_{x} f g\right)
$$

When the buyout is paid through a consumption tax, producers lose the tax revenue when the program is terminated, whereas in the US Treasury buyout case, this is not true because producers receive a consumption tax equivalent check from the federal Treasury.

\section{Conclusion}

For producer quota buyouts, producers clearly prefer, for equivalent quota values, to be compensated with monies from the Treasury, rather than through a consumption tax. This is true even when producers are paid an inflated quota value.

\section{REFERENCES}

[1] A. Schmitz and T. G. Schmitz, "Benefit-Cost Analysis: Distributional Consideration under Production Quota Buyouts,” Journal of Benefit-Cost Analysis, Vol. 1, No. 1, 2010, Article 2.

[2] T. G. Schmitz and A. Schmitz, "Compensation and the Twin Producer Gains from Production Quotas," Theoretical Economic Letters, Vol. 1, No. 3, 2011, pp. 70-72. doi:10.4236/tel.2011.13015

[3] R. E. Just, D. L. Hueth and A. Schmitz, "The Welfare Economics of Public Policy: A Practical Approach to Project and Policy Evaluation,” Edward Elgar Publishing, Cheltenham, 2004.

[4] J. Womach, “Tobacco Quota Buyout,” CRS Report for US Congress, 2005. http://www.nationalaglawcenter.org/assets/crs/RS22046.p df 